\title{
The forecasting power of the brand: contribution to the increase in the value of the company's intangible assets
}

\author{
Olesya Sevostyanova ${ }^{1}$, and Svetlana Petuhova ${ }^{1}$ \\ ${ }^{1}$ Novosibirsk State University of Economics and management, 630099, Kamenskaya Str., 56, Novosibirsk, Russia
}

\begin{abstract}
The article is devoted to the study of the cost characteristics of brand power, determining and forecasting the revenue of companies generated by brand power. Under the influence of the growing role of the brand, there is now an increase in the range of using its valuation as the most important of the company's intangible assets, including managing the business development strategy. It is proved that brand competitiveness becomes the most important component of the company's overall competitiveness. Using the private V-RATIO method, the cash flow generated by the brand itself is determined, and sales volumes are calculated under the influence of brand and non-brand factors for the "Shoes of Russia" and "KARI" trading companies. The cost of the studied brands is calculated and the curve of falling brand strength without supporting measures is determined.
\end{abstract}

\section{Introduction}

Currently, most trading companies note a negative trend in reducing the volume of sales of goods and services, which is associated with a glut of the market, a significant decrease in demand. Customer-oriented sales technologies will make it possible to interest a buyer of a certain gender and age who has specific financial resources [1].

It is possible to implement customer - oriented sales strategies using a reputation tool-the brand. At the same time, the content of such a definition as "brand" can be considered from various points of view, both legal, psychological, and economic.

James R. Gregory in his research [2] States that the brand cannot be used as the name of a product or service, company or organization. The brand combines all human experience, its perception of the company as a whole and the product produced by this company in particular. David D'alessandro in [3] offers a more precise interpretation of the definition of "brand" — it is more than advertising and marketing activities. The brand is reflected in the thoughts and emotions of people who have seen this brand name or heard its name. Professor Jean $\mathrm{N}$ in [4] says that a brand is a household name for a product or company that has a stimulating effect on customer behavior.

From an economic point of view, brand strength is an important element of the company's overall competitiveness, laying the basic basis for the competitiveness of MTP (material and technical potential), personnel, and the product itself, resulting in the competitiveness of trade potential and Finance, which is evaluated by specific economic indicators [5].
The elements of a trading company's competitiveness are shown in figure 1 .

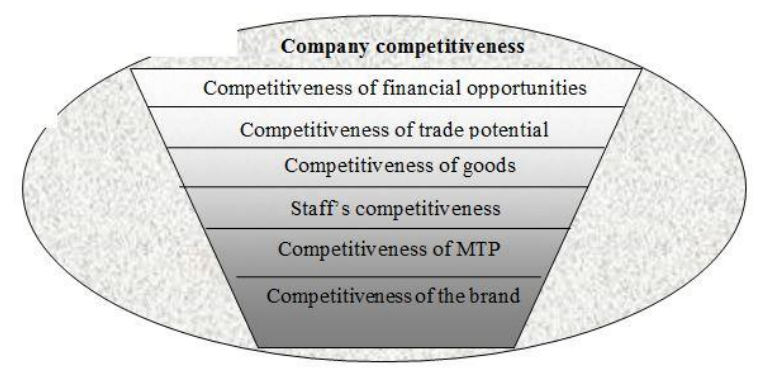

Fig. 1. Elements of trading companies ' competitiveness.

Under the influence of the brand's growing role, there is now an increase in the range of using its valuation as the most important of the company's intangible assets, including managing the business development strategy. Estimated characteristics of future cash flows generated by the brand can serve as important information for investors and creditors of the company. [7].

Brand strength can be managed by implementing a conceptual model for evaluating its cost characteristics.

\section{Methods for determining the cost characteristics of brand strength}

Among the existing methods for determining the cost characteristics of brand strength, the most frequently used approaches are cost-based, comparative, and revenue-based.

The cost method is the addition of expenses when creating a brand. Most critics consider this method not

\footnotetext{
* Corresponding author: opt_el@mail.ru
} 
completely incorrect, since the strength of the brand is not comparable to the amount of money invested in its creation [8]. The economic nature of the brand is reflected when using comparative methods. The disadvantages include the attachment of final ratings to the parameters of the compared brands, as well as the features of using the multiplicative method in the absence of a single calculation base, and the problematic choice of an analog brand when using the rating/ranking method. As a result, comparative methods do not allow us to objectively determine the possibility of increasing or decreasing the cost characteristics of the brand[9].

The revenue approach practically solves these problems. The method of discounting cash flows, which is part of the revenue approach, allows you to build an assessment of the cost characteristics of the brand, based on the results of its activities in the future, taking into account the risks inherent in the brand [10].

The most interesting of the revenue approaches is considered to be V-RATIO. The V-RATIO method transforms the "consumer essence" of a brand into a financial model, distinguishing the brand itself from the value of intangible assets. Thus, the rate of decline in the brand's own strength is determined if there are no promotional incentives. The V-RATIO method is also used to evaluate the effectiveness and profitability of the brand [11].

\section{Results and Discussion}

At the first stage of the V-RATIO method, the cash flow that directly generates the brand itself, sales volume, is determined under the influence of brand and non-brand factors (Table 1).

Table 1. Load on sales factors for brands in 2019.

\begin{tabular}{|c|c|c|c|}
\hline & $\begin{array}{c}\text { Share of } \\
\text { non- } \\
\text { brand } \\
\text { sales, \% }\end{array}$ & $\begin{array}{c}\text { Share of sales } \\
\text { influenced by } \\
\text { current } \\
\text { communicati } \\
\text { ons, \% }\end{array}$ & $\begin{array}{c}\text { Share of sales } \\
\text { influenced by } \\
\text { the brand's } \\
\text { own } \\
\text { strength,\% }\end{array}$ \\
\hline $\begin{array}{c}\text { «Shoes of } \\
\text { Russia » }\end{array}$ & 20 & 15 & 65 \\
\hline «KARI» & 30 & 30 & 40 \\
\hline
\end{tabular}

As we can see, the Shoe brand "KARI" shows an excess of non-brand sales of goods and services (60\%). This situation reveals the vulnerability of the KARI brand and the instability of its position in the market. Discontinuing promotional and marketing activities can significantly weaken the company's market position and reduce its competitiveness.

A weak brand is not able to generate stable cash flows and needs expensive advertising campaigns. In this case, KARI managers need to plan the effect of current communications not only in the short term, but also take care of the long-term attachment to the brand. Otherwise, there is a significant risk that the company's revenue will fall immediately after the advertising campaign.

Customer loyalty to the Shoes of Russia brand is expressed in a significant share of brand sales $(65 \%)$. This fact indicates an effective investment in the brand.

Following the V-RATIO method, the next step is to calculate the amount of operating profit generated by the brand. We use the EBITDA indicator, which is $19.3 \%$ for the Shoes of Russia brand and $16.5 \%$ for KARI.

The main action of the V-RATIO method is to calculate your own financial flow, which will generate the brand's own strength without any advertising activities. Consequently, to adjust the EBITDA indicator, the 2019 advertising budget is "returned" to operating profit. The amount of free financial flow generated by the" Shoes of Russia "and" KARI " brands in 2019 is reduced by the amount of income tax.

As a result, the revenue generated by the studied brands is discounted in accordance with corporate rates, their amount is determined, and then we add the extended cost of the studied brands in the post-forecast period. It is recommended to calculate the extended value of brands using the Gordon formula, taking into account the decrease in cash flows generated by brands in the long term. Calculations were made using a negative value of the income growth rate $g=-2$ (Table 2.3).

The drop in the value of the brands studied is shown in figure 2 .

Table 2. Calculating the cost of the « Shoes of Russia » brand.

\begin{tabular}{|l|c|c|c|c|c|c|c|}
\hline Index & $\mathbf{2 0 1 9}$ & $\mathbf{2 0 2 0}$ & $\mathbf{2 0 2 1}$ & $\mathbf{2 0 2 2}$ & $\mathbf{2 0 2 3}$ & Extended cost & Total \\
\hline FCF, mln. Rub. & 736,24 & 625,80 & 531,93 & 452,14 & 384,32 & & \\
\hline DF & 1,16 & 1,3456 & 1,5609 & 1,8106 & 2,1003 & & \\
\hline PV, mln. rub. & 634,69 & 465,07 & 340,79 & 249,72 & 182,98 & 1016,56 & 2889,81 \\
\hline
\end{tabular}

Table 3. Calculating the cost of the brand « KARI».

\begin{tabular}{|l|c|c|c|c|c|c|c|}
\hline \multicolumn{1}{|c|}{ Index } & $\mathbf{2 0 1 9}$ & $\mathbf{2 0 2 0}$ & $\mathbf{2 0 2 1}$ & $\mathbf{2 0 2 2}$ & $\mathbf{2 0 2 3}$ & Extended cost & Total \\
\hline FCF, mln. Rub & 688 & 481,6 & 337,12 & 235,98 & 165,17 & & \\
\hline DF & 1,16 & 1,3456 & 1,5609 & 1,8106 & 2,1003 & & \\
\hline PV, mln. Rub & 593,1 & 357,9 & 215,98 & 130,33 & 78,64 & 436,89 & 1812,84 \\
\hline
\end{tabular}




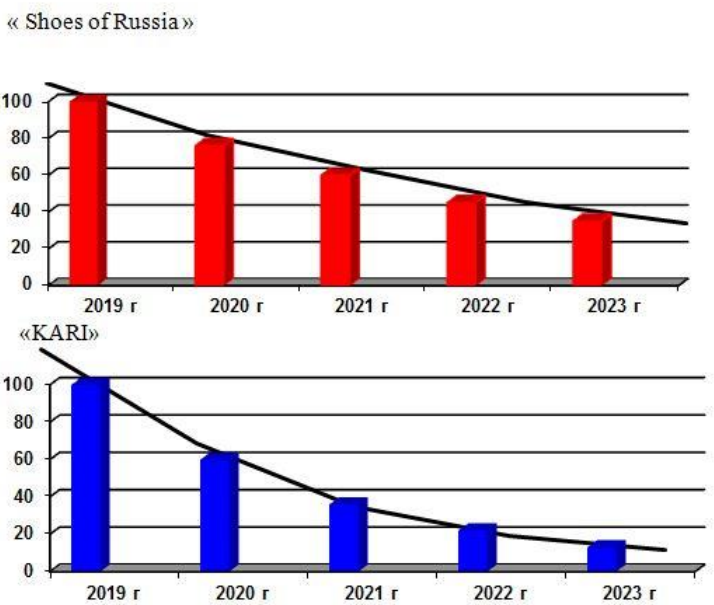

Fig. 2. Falling revenue generated by the "Shoes of Russia" and "KARI" brands.

The presented curves clearly reflect the decline in revenue generated by the "Shoes of Russia" and "KARI" brands, which occurs in the event of termination of promotional activities. We see that the "KARI" brand is "losing" its strength faster, and revenues are falling rapidly. Explain the different rates of revenue decline can be attributed to the current strength of the brand: the greater it is, the longer it will take customers to show their loyalty to the brand. Thus, the main task of a brand Manager in relation to a losing brand is to make management decisions that can "level out" the decline curve.

\section{Conclusions}

1. In the Era of production compression and reduced demand, the main driving element of success, which helps to strengthen the company's competitiveness and stabilize its position in the market, is the brand. It lays the basis for the competitiveness of the material and technical potential of the company, personnel, and the product sold, and increases the competitiveness of trade potential and financial flows.

2. As a result of increasing the role of the brand, the range of use of its valuation as the most important of the company's intangible assets is expanding. Among the well-known valuation approaches, the most appropriate approach for determining the brand value is the revenue approach, namely the private V-RATIO method.

3. As a result of comparing the sales volumes of such Shoe brands as "Shoes of Russia" and "KARI", it was found that in the latter case, there is an excess of nonbrand sales of goods and services (60\%). This indicates the weakness of the KARI brand and its inability to generate stable cash flows without being tied to stimulating advertising events.

\section{References}

1. O. G. Sevostyanova, Z. A. Kapelyuk. Organizational and economic mechanism for ensuring the competitiveness of a retail service enterprise // Bulletin of the Belgorod University of cooperation, Economics and law. Volume 73. No. 6. Pp. 81-91 (2018)

2. James R. Gregory. Using a corporate brand, NTC Business Books, 233 (1997)

3. David F. d'alessandro Brand Warfare: 10 rules for building a killer brand, 240 (2003)

4. Jean-Noel Kapferer. Remark: Les marques à l'épreuve de la pratique - 500 marques passées au crible, Eyrolles, 256 (2011)

5. L. Nyurenberger, I. Sevryukov, O. Sevostyanova, N. Shchetinina, O. Leushina, T. Varyukha. Current aspects of ensuring strategic competitiveness in Commerce. Achievements in Economics, business and management, Volume 131 "New silk road: business cooperation and prospects for economic development", Saint Petersburg - Prague. NSRBCPED 2019. - Pp. 356-360 (2019)

6. al rice, L. rice the origin of brands: how product evolution creates limitless opportunities for new brands. New York : HarperCollins books, 308 (2012)

7. D. A. Aaker, Management Brand Equity: capitalization of the brand value. New York, 273 (1991)

8. J. Roos, G. Roos, L. Edvinsson, L. Dragonnettni. intellectual capital: navigating in the new business landscape, Basingtoke, Macmillan, 142 (1997)

9. H. K. Chi, H. R. Yeh, M. W. Huang, M. W. The Influences of advertising endorser, brand image, brand equity, price promotion on purchase intention: The mediating effect of advertising endorser, The Journal of Global Business Management, vol.5(1), PP. 224-233 (2009)

10. Interbrand. The best global brands of 2019. URL: https://www.interbrand.com/best-brands/bestglobal-brands/2019/ranking/

11. Yushkova L. V. competitiveness of the food market in Siberia/ Innovative management and educational excellence through vision 2020: proceedings of the 31 st international conference Of the Association for business information management. Milan: IBIMA, Pp. 1659-1663 (2018).

12. O. G. Sevostyanova. Managing the competitiveness of a commercial enterprise. Bulletin of the Belgorod University of cooperation, Economics and law. Volume 65. No. 4. Pp. 291-301 (2017)

13. N. Aga, M. M. Goldman \& J. S. Dixon, rebranding: the effect of team name change in onclub revenue. European Sport Management Quarterly, vol. 16, No. 5, PP. 675-695 (2016)

14. M. Yasin, A. Shamim, brand love: the intermediary role in purchasing intentions and word of mouth, journal of business and management, Volume 7, pp. 101-109 (2013)

15. J. J. Brakus, B. H. Schmitt, L. Zarantonello. Brand Experience: What Is It? How Is This Measured? 
Does This Affect Loyalty? Journal of Marketing, vol. 73, PP. 52-68 (2009). 